\title{
What it takes to be an entrepreneur in Romania
}

\author{
Tatiana SEGAL \\ The Bucharest University of Economic Studies, Bucharest, Romania \\ tatianasegal@hotmail.com \\ Shahrazad HADAD \\ The Bucharest University of Economic Studies, Bucharest, Romania
}

\begin{abstract}
For more than three decades now, famous and relatively famous theoreticians from around the world and from Romania having different specialisations and statuses within society (from economists who work in universities and research centres to those involved in political decisions, from anthropologists to sociologists, from political analysts to jurists) and also practitioners that have transposed their ideas into reality by creating their own small or medium enterprises which support their roles within both the national and international economies. Additionally, statistics, be them undertaken by international organisations such as UNO or the EU or other national institutes reveal the ever increasing share of SMEs within the GDP, employment, turnover and the list may continue. The concern of policy makers of encouraging the development of entrepreneurship is manifested both in the legislative and financial frameworks by granting tax exemptions to those starting a business, by awarding them financing under certain conditions or by fostering the possibility of their accessing various European funds. This article seeks to provide the necessary support to the persons/entities that would or should take the necessary steps in order to define the job of the entrepreneur or undertaker in the economic field in general and not particularly in the construction field making a review of the current entrepreneurial phenomenon in Romania and analysing the opinions of different entrepreneurs with respect to the requirements of the jobs they have. Purposively, we designed and distributed a questionnaire in Bucharest. The number of valid responses is 47 and even if the sample is not representative, we consider the findings a step forward to defining the entrepreneur job.
\end{abstract}

Keywords: SMEs, entrepreneur, entrepreneur job, job requirements, skills and abilities.

\section{The past at a glance}

Older and newer Romanian specialised papers, such as the ones published by well reputed authors such as Nicolescu et al. (2003), Nicolescu (2001), Antonoaie et al. (2013, 2014), and the list may continue, debate on the sustainable rebuilding of Romanian economy in which the central role is played by SMEs. Consequently, these authors bring into discussion and analyse the mutations that occur in the general management of the organisation (covering issues such as knowledge management, managerial methods imposed by reengineering, know-how transfers, to modern business management methods), modern approaches in the management discipline (ranging from studying the environment in which the organization develops and activates, to quality management, from production and supply management, to human resource management, to sales management), the specificity of the leadership and organization of different types of organizations (from the so-called traditional farms, industrial, construction and transport, enterprises to relatively newer, 
but given the expansion of wholesale, public management, or virtual enterprise management) and, ultimately, the economic efficiency of the phenomena considered for discussion. At the same time, the entrepreneurial and business concepts are discussed together with their characteristic features and their limits, the role of planning, business organization, innovation and its sources as an indispensable factor of entering and maintaining one's position on the market, presenting entrepreneurial strategies, the importance of strategic decision in business, leader position (Dima and Ghinea, 2016; Dima et al., 2016), etc.

However, from the cited papers there is no clear definition on what an entrepreneur/undertaker is. No one emphasises the importance of his/her training, whether he/she needs any particular training, which are the fields or whether simply his intuition would suffice for setting up a business. There are not any discussions around who can be an entrepreneur or if this job/trade is reserved to the chosen ones. There are no clear indications whether to be an entrepreneur is a job or not. Additionally, in the English specialised literature being an entrepreneur is not a profession, whereas other authors regard it as a discipline that can be learned (Lange, 2012). The French literature is represented by Fayolle (2003, 2004) and Fayolle et al. (2006) who uphold entrepreneurship as a trade that can be learned. Ergo, the literature does not show which the traits that would actually characterise such a trade are, which the common characteristics of the entrepreneur, manager, director and leader are or which the differentiators among these concepts are.

Another topic that is left aside is that of generating the entrepreneurial spirit. We consider that people's option of developing their own business has not emerged out of nothing, but from a less discussed reality. Even during the 45 years of communism, people took their lives into their own hands becoming autonomous. Their fields of activity were extremely varied. At the countryside there were still peasants not belonging to any cooperatives, shepherds who respected the transhumance, or closer to the cities, there were peasants who sold the products made on their inherited lands. Florists, shoemakers, milliners or tailors belonged to this category. Other craftspeople belonging to cooperatives (hairdressers, manicurists, pedicurists, cosmeticians, etc.), who were paid the minimum salary compensated by a commission from the sales that exceeded their targets wished to be their own bosses. For a relatively short period of time triggered in 1967 by the Romanian Communistic Party, for the first time in a country in the socialist camp, the idea of economic recovery was launched by adopting a program aimed at decentralizing economic decisions and increasing corporate responsibility, encouraging private initiatives (building private property housing, craft workshops, opening of restaurants and confectioneries by tenants). The mandate manifested mainly in tourism which began to develop at European level and in public nutrition. Many of the bed and breakfasts, restaurants, confectioneries, camps set up at that time, some of which became good landmarks, resisted until the mid-1980s, despite the restrictive measures taken against them. Another spurred sector was that of construction. These pioneers are the proof of traditions in the field of entrepreneurship.

\section{Current situation of entrepreneurship in Romania}

The White Charter of SMEs (WCSME) comprises the in-depth evaluation and examination of the status of these enterprises as well as the enterprises in Romania at national, regional, 
sectorial and at county levels. In 2016, the accent was placed on the recent performances and highlights of the main difficulties that the SMEs are confronted with. The purpose of WCSME research is to establish at national level a set of strategic and tactical priorities and ways through which to reduce at least a part of the obstacles that the SMEs face. At the same time, the charter targets the reduction of the impact of the contextual threats and the capitalising of national and international opportunities.

PICBE $\mid 466$

The educational system, by the curricula adopted at the lower secondary education and at the undergraduate level and also by means of extracurricular activities (contests and national and international competitions organised by different associations or companies), and other training and education campaigns dedicated to vulnerable groups, it seeks to develop the entrepreneurial spirit and teach the young generation (and not only) to create and develop their own companies in most various fields. This being the mission of our university, a large number of disciplines and practical and extracurricular activities unveil to students the steps they need to take in order to set up a company (documents and papers to compile, market research, feasibility studies, business plan, etc.), the complexity of the simplest business, what the entrepreneur has to know, which are the qualities, at least theoretically, that he/she should have and nurture. The thing that they do not know is that in the Romanian Job Classification (RJC 2017) the job of being an entrepreneur, as in an undertaker, a person that sets up or takes over a company, does not exist. Each job is defined by a certain type of training that ensures specific skills and abilities.

In 2016, the $14^{\text {th }}$ research Report released by the National Council of SMEs (NCSME)[Romanian equivalent CNIPMMR], The White Charter of SMEs in Romanian, based on the interviewing of 1096 entrepreneurs/undertakers, has reached the following conclusions:33.58\% of the enterprises find the evolution of the economic environment in Romania as inhibiting development, and $48.27 \%$ of the SMEs find it neutral; $13,78 \%$ of the companies estimate that the evolution of the Romanian business environment on the whole year 2016 is going to be favourable for the SMEs; bureaucracy (61.41\%) excessive taxation (54.74\%) followed by corruption (45.16\%) and excessive control (44.98\%) are the most frequent difficulties faced by the SMEs; only $6 \%$ of the investigated persons consider that the economic evolution is going to be positive; better access on the markets $(45.99 \%)$ is the main positive effect that the Romanian EU accession had over the SMEs; $81.66 \%$ do not intend to access structural funds in the future; $0.18 \%$ received the approval for the project that they submitted; around $71.99 \%$ fund their activities on their own sources (9).

NCSME consider the notions of entrepreneur and/or undertaker as readily known terms that need not be defined anymore. At the same time, they are preoccupied with finding global solutions applicable to most of the SMEs, and not to verify the level and the training of the people who manage them.

In the Romanian Job Classification 2017, the term entrepreneur can be found only twice: as funeral services entrepreneur (code 516301) and social economy entrepreneurs (code 112032). This occupation is categorised in the $5^{\text {th }}$ major group that comprises workers in the services field whose preparation level is 2 (medium studies). The second mention is social economy entrepreneurs (code 112032). This job is categorised in the first major group that includes members of the legislative bodies, executive bodies, high leaders of public administration, leaders and superior state workers whose training levels are undefined given the fact that they are governed by other regulations.

Among the items used to characterise and define the social economy entrepreneurs,

DOI: 10.1515/picbe-2017-0050, pp. 467-474, ISSN 2558-9652| Proceedings of the $11^{\text {th }}$ International Conference on Business Excellence 
we can find different headings. So, if in the "necessary abilities and necessary aptitudes" headings we can include items that belong to minimum communication abilities such as verbal comprehension, or written text comprehension, whereas the occupational interests heading contains entrepreneurial interests - which is rather difficult to be explained in this misty context. In the heading values and needs attached to work we can find "networking" and "independence" and in the necessary knowledge heading the first place should be held by Administration and Management. But there is no explanation of what a social economy entrepreneur represents; therefore the whole entrepreneur job concept does not have a legitimate framework.

\section{Research methodology}

Starting from Fayolle's (2004) idea reaffirmed by Filion (2006), according to whom entrepreneurship is a regular trade/job respectively a trade that can be learned, and starting from the absence of this trade from the RJC 2017, we aim to find out the opinion of Romanian entrepreneurs with respect to the requirement of such a trade/job. Therefore, we identified the problem that even though reality depicts SMEs as playing an increasingly important role in the Romanian economic life, the occupation/job of the actual creators of SMEs is not clearly defined. Consequently, we try to answer the question "Which are the requirements specific for the entrepreneur job?" and we formulated two working hypotheses:

H1: The main traits of entrepreneurs are passion, innovation and perseverance

H2: The entrepreneurs take responsibilities and risks more as compared to other types of workers

In order to conduct this study, we designed a questionnaire that we distributed by means of Google Docs in the month of November. We managed to collect 60 answers out of which 13 were not valid. Consequently, the study was conducted over a sample of 47 . Though this sample does not respect the norm of representativeness, we consider that it constitutes a pilot study, and based on the results, the research on the requirements of the entrepreneur job can be extended. The research tool comprises 26 questions out of which some represent key questions, whereas the rest represent complementary questions. We are going to restrict our analysis to the defining questions and we are going to regroup them according to the previously enunciated hypotheses. All the graphics and illustrations are the result of our own research.

\section{Results and analysis}

The entrepreneurs stand out through passion, innovation and perseverance $(Q / R 3,6,10$, $13,14)$. Everyone is subject to decision making with respect to their career. If being an entrepreneur is a trade/job, then the decision to follow such a career is based on motivation. We checked this on our sample (Q/R 3), and the answers illustrated in Figure 1 show that wanting to be their own boss and having the business idea influence equally the decision of becoming an entrepreneur, followed only on the third place by passion. 


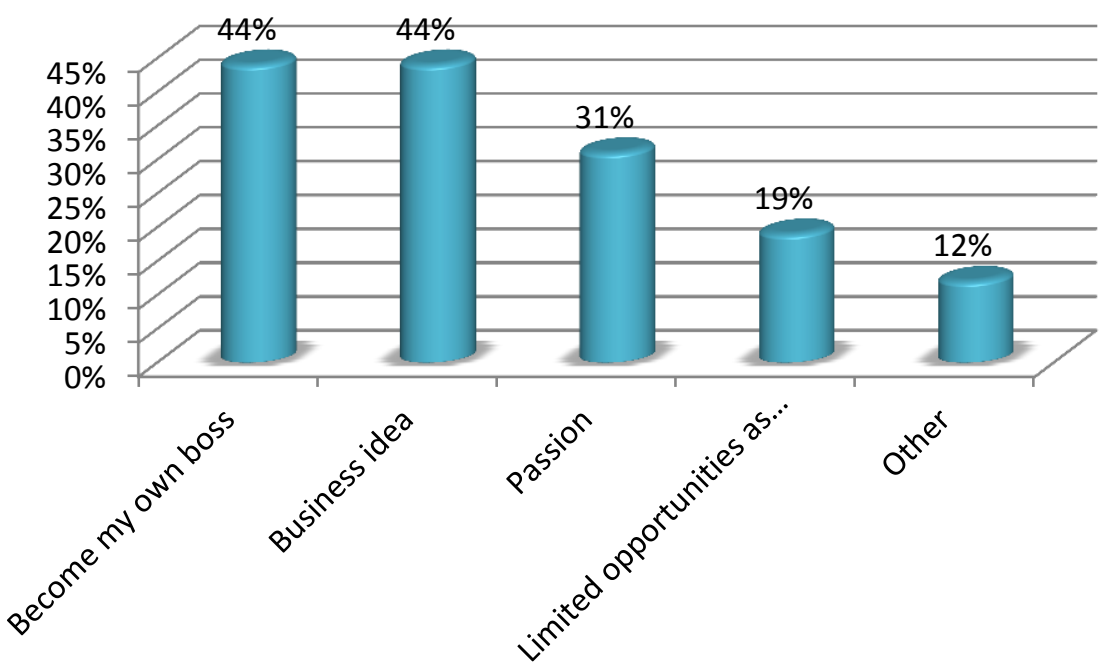

PICBE | 468

Figure 1. Reasons for becoming an entrepreneur

Source: Authors' own research results.

Should we take into consideration the implications behind the idea of them wanting to become their own bosses this means them assuming responsibilities and taking risks not only for the future business and employees but also for their own families, and behind the business idea lays innovation and perseverance (Cantaragiu and Hadad, 2013), indicating that the answers we collected constitute a starting point for both our working hypotheses.

Practicing any type of trade/job entails developing certain qualities and characteristics, and the same stand for the entrepreneurial trade. Consequently, by using question 13 we wanted to point out a series of characteristics that differentiate an entrepreneur from other persons. Every characteristic was rated from 1 (the least important) to 7 (the most important). Figure 2 shows that even though passion ranks second, and wish to innovate ranks sixth, two of the characteristics embedded in H1 are found conjointly.

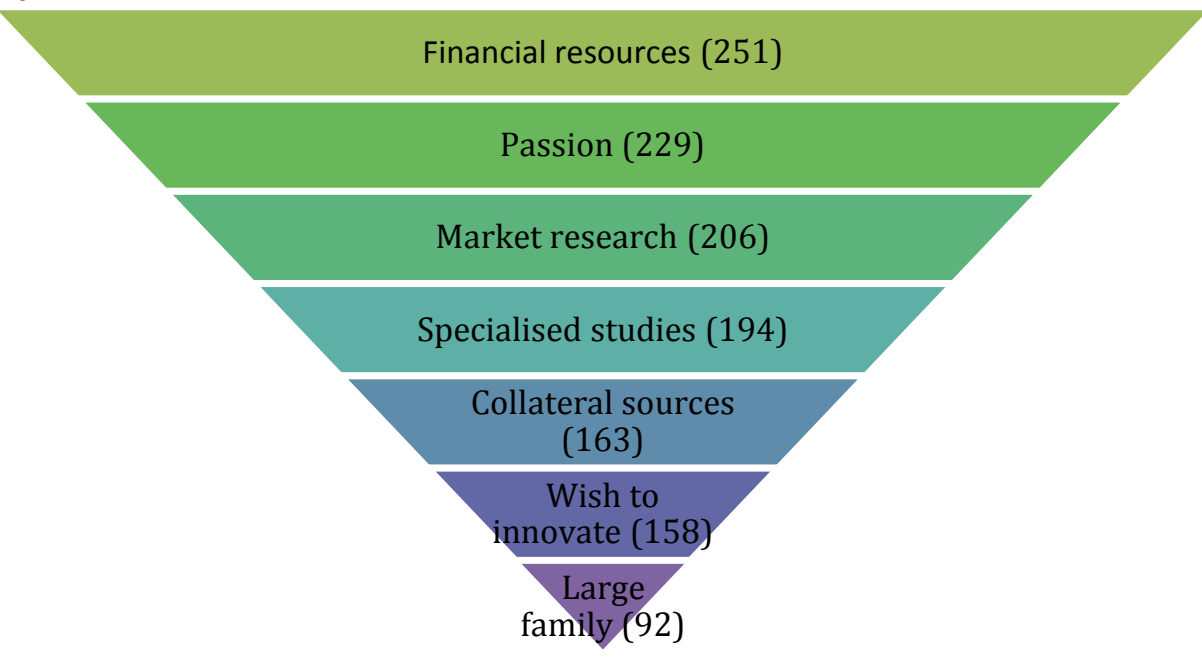

Figure 2. Characteristics of the entrepreneur

Source: Authors' own research results.

If we analyse the meaning that the respondents attribute to the notion of passion, (Q/R 14), we are to find out that ranked secondly there is the ability to invent/create a new 
business (Figure 3). We want to underline that innovation is manifested both through seeking for the new, and through bringing the new by setting up an enterprise.

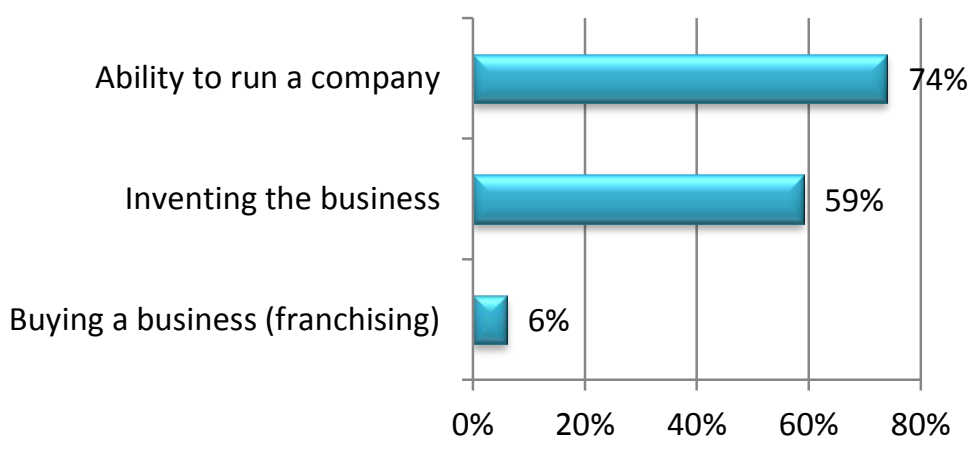

PICBE | 469

Figure 3. Meanings of passion

Source: Authors' own research results.

Besides, according to the respondents $(\mathrm{Q} / \mathrm{R} 6)$, the moment the passion of doing something emergences (42\%) represents itself the best moment to start a business (Figure 4). Additionally, the idea of becoming an entrepreneur can also appear while being unemployed. Both experience and youth, though being two rather mutually exclusive dimensions, rank equally (19\%).

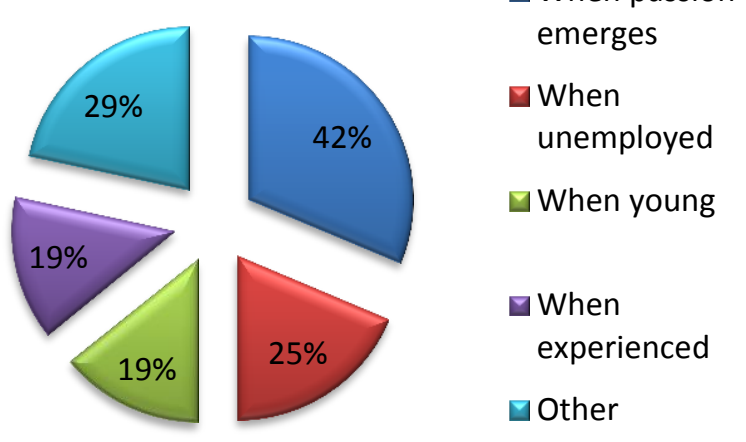

Figure 4. The moment for starting a business

Source: Authors' own research results.

Q/R 10 was intended to find out how the entrepreneurs assess the necessary qualities for becoming an entrepreneur. Similar to the characteristics question, the respondents rated their answers from 1 (the least important) to 7 (the most important) (Figure 5). The results were somehow surprising when we found out that perseverance that have been highly praised by theoreticians was ranked last, being outperformed by tolerance which was the most important quality. The explanation could reside in the fact the entrepreneurs being confronted with numerous ideas and conflicting situations to have reached the conclusion that tolerance rather than perseverance is more useful in reaching one's objectives with respect to certain partners. Neither innovation/inventiveness is among the most important qualities, instead, of second importance is independence, and we therefore conclude that the passion of doing something could be more about independence rather than perseverance. 


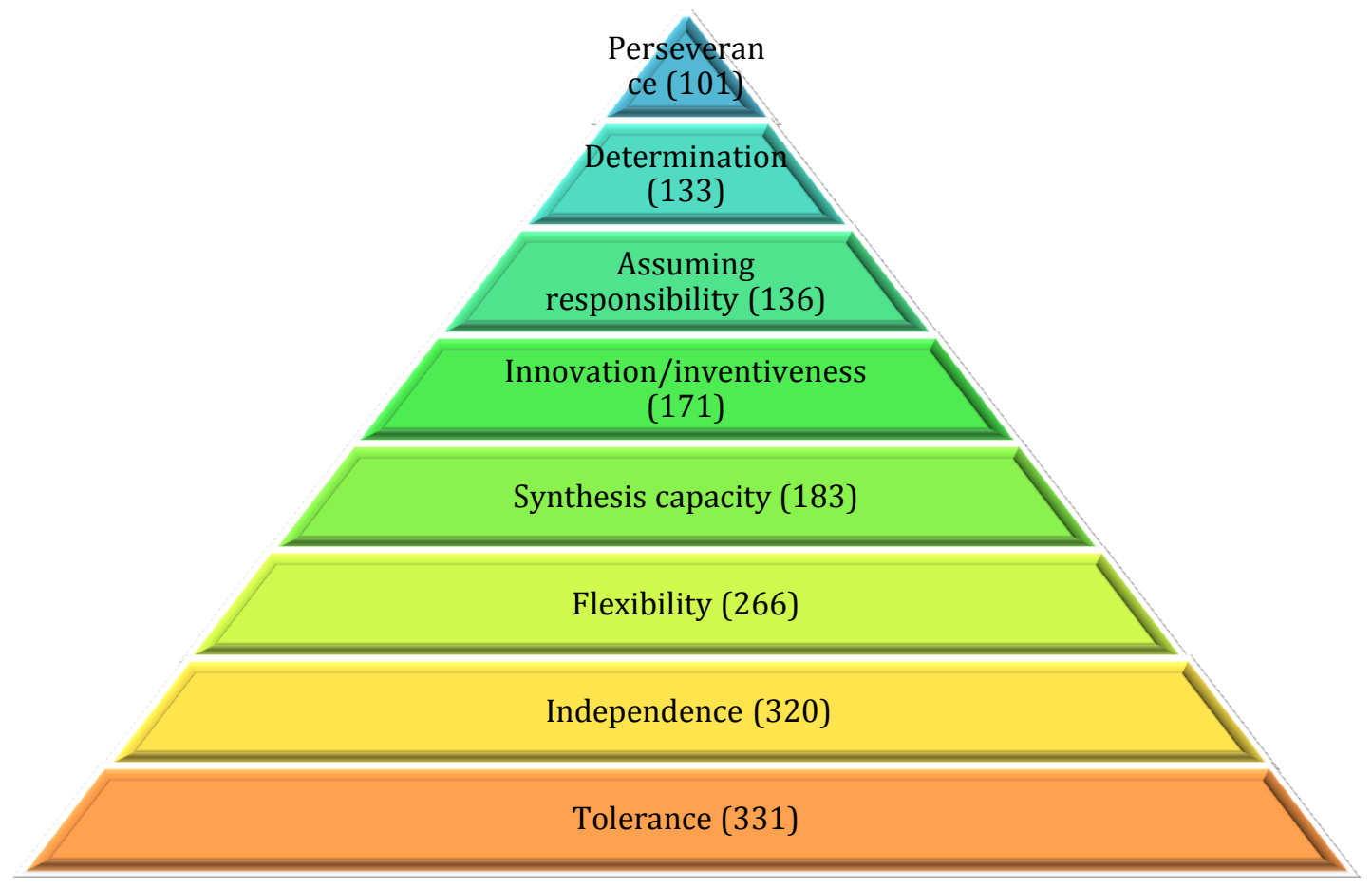

PICBE $\mid 470$

Figure 5. Perceived qualities of the entrepreneur

Source: Authors' own research results.

Though, apparently $\mathrm{H} 1$ is confirmed passion, innovation, perseverance being among the options of the entrepreneurs, this hypothesis is infirmed in reality since the entrepreneurs do not consider these elements as cornerstones for them.

\section{The entrepreneurs take responsibilities and risks $(Q / R 7,8,9,15)$}

Any type of activity, regardless of the place where it is undertaken, its nature, or the person performing it, it automatically implies taking some risks. From the plethora of risks, sacrifices, and perils/dangers that an entrepreneur could face, we are going to limit our analysis to four types of risks. Even if the entrepreneur does not realize it the moment he/she starts the business, the entrepreneur is in an instrumental relationship with the work he/she carries out and he/she has to solve the dilemma: is he/she at the service of the business or the business is at his service. Over time, he strikes a balance between the two factors. However, entrepreneurs who have responded to their personal risks (Q / R7) consider that they first sacrificed their "free time" and then, equally, "family life" and "Friends" (Figure 6). 


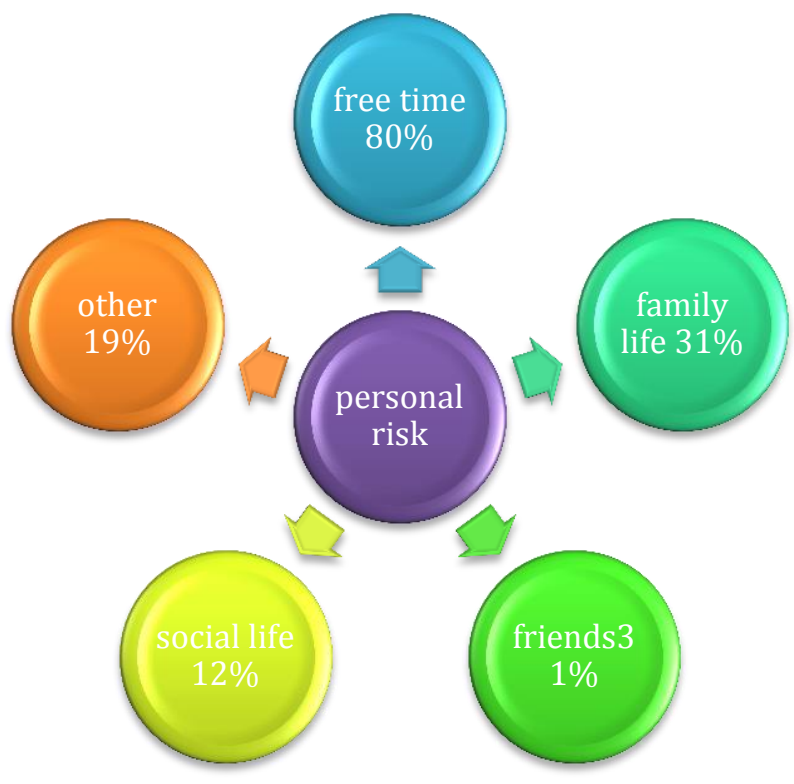

PICBE | 471

Figure 6. Personal risks

Source: Authors' own research results.

"Social life" is the least sacrificed because within it can be established further professional co-operation relations. Strictly, in relation to the object of activity, of all types of risk, the objective risks are, in our opinion, the only ones that can be predicted, calculated, and sometimes, even eliminated. Considering the individual perception of objective risks, we asked the entrepreneurs their opinions with respect to three major objective risks: financial risk, competition and administrative problems (Q/R 8). Contrary to our expectations, the financial risk was rated higher than administrative problems of competition in terms of potential risks that could endanger business.

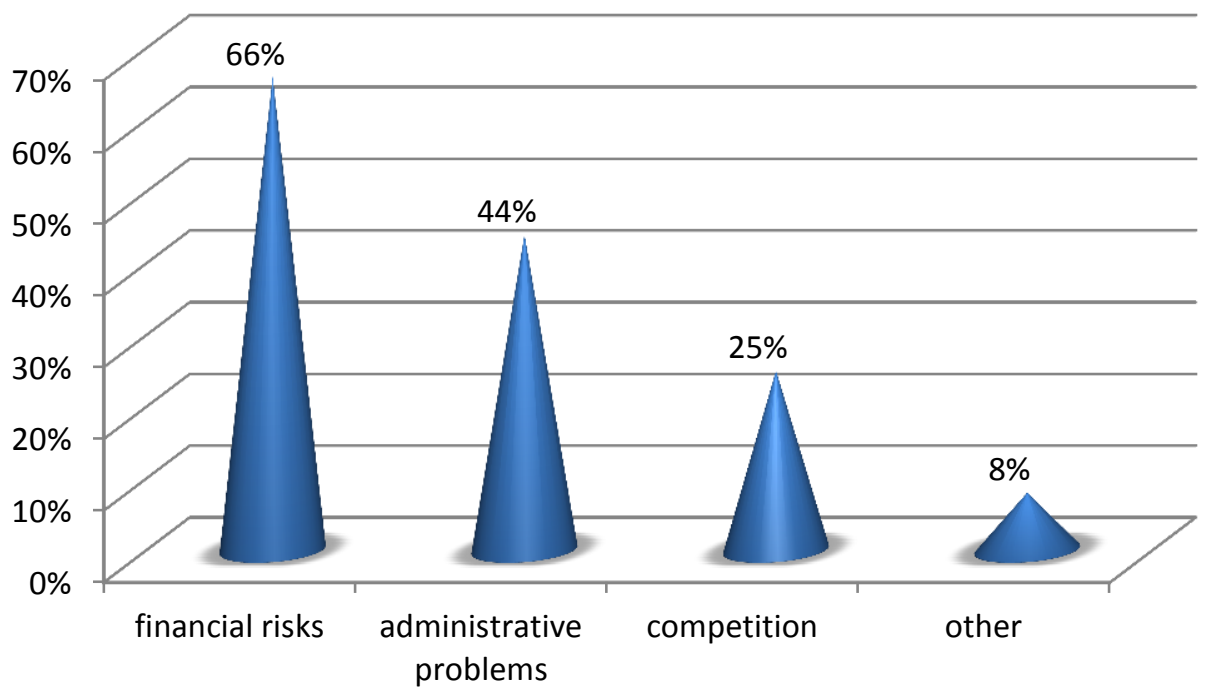

Figure 7. Objective risks

Source: Authors' own research results.

From the discussions we had with the young entrepreneurs, we know that financial risks are very high, but we do not consider that they are listed so far apart from the other types of risks taken into account. 


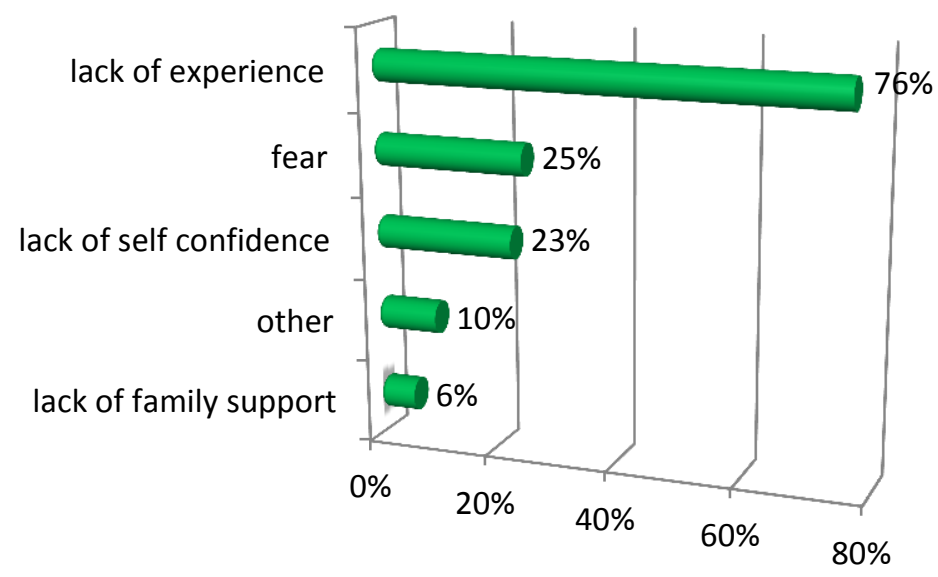

PICBE | 472

Figure 8. Subjective risks

Source: Authors' own research results.

Most of the times, personal risks correlated with objective risks get to emphasize subjective risks. Through the answers we got, we also wanted to check this hypothesis. As Figure 8 reveals, our supplementary supposition did not hold true, because the impact of the lack of family support is around 6\%, while in the personal risks category, family sacrifices level up to $31 \%$. It seems rather strange to include the lack of experience among subjective risks; on the other hand, from the point of view of tenure, this item is an objective fact. But given that each individuals have their own perception with respect to accumulated experience, and this explains the impact it has.

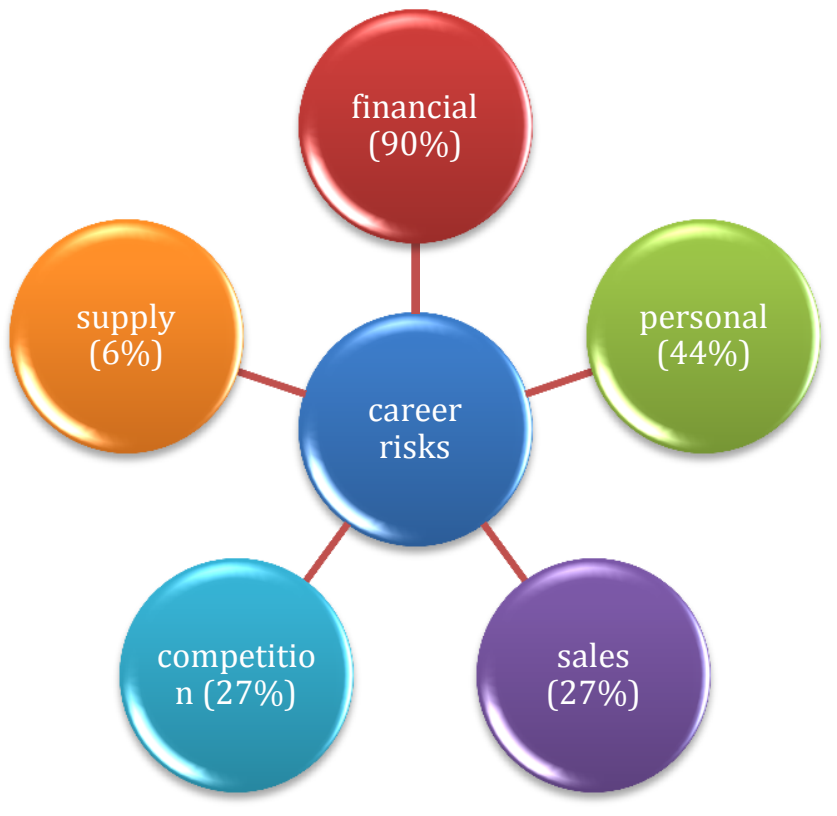

Figure 9. Career risks

Source: Authors' own research results. Concluding, a synthesis of the risks to which the entrepreneur is exposed and as a means of checking the honesty of the answers, we conjointly analysed under the category "risks assumed throughout the career", or simply put "career risks" (Q/R 15) some of the previously presented risks. This type of risks (illustrated in Figure 9) includes: financial 
risks, personal risks, sales risks, competition risks and supply risks. As expected, by taking into account the foregoing, financial risks and personal risks recorded the highest values, additionally confirming the last hypothesis that entrepreneurs take risks to a greater extent as compared to other workers.

\section{Conclusions}

PICBE | 473

As we stated from the very beginning, the analysis carried out can only be considered as a pilot test. The fact that hypothesis 1 has not been fully confirmed as we expected, may be the result of a wrong wording of the questions and/or the choice of unrepresentative items. We plan to resume research and, at the same time, expand the sample. The fact that hypothesis 2 has been fully confirmed demonstrates that the entrepreneurial activity differs from other occupations and should find its place in the RJC.

\section{References}

Antonoaie, N., Antonoaie, C., Antonoaie, V. (2013). Antreprenoriat şi afaceri, I Antreprenoriat, Braşov: Editura Universităţii Transilvania.

Antonoaie, N., Antonoaie, C., Antonoaie, V. (2014). Antreprenoriat şi afaceri, II Afaceri, Braşov: Editura Universităţii Transilvania.

Cantaragiu, R. and Hadad, S. (2013). The Importance of Play in Overcoming Fears of Entrepreneurial Failure, 14th European Conference on Knowledge Management ECKM, Lithuania, 2013, in Proceedings of the 14th European Conference on Knowledge Management - ECKM, 833-843.

Cel de-al 14-les Raport de cercetare al Consiliului Naţional al întreprinderilor private mici şi mijlocii din România, „Carta Albă a IMM-urilor din România”. (2016). Retrieved from http://cnipmmr.ro/2016/07/11/cel-de-al-14-lea-raport-de-cercetare-al-cnipmmrcarta-alba-a-imm-urilor-din-romania/.

Clasificarea ocupaţiilor din România (COR)[Romanian Job Classification (RJC)]. (2017). Retrieved from http://www.rubinian.com/cor_1_grupa_majora.php.

Conferința Naţională a Partidului Comunist Român. 6-8 decembrie 1967. (1971). Bucureşti: Editura Politică, Retrieved from http://www.ioanscurtu.ro/programul-ideologic-alp-c-r-lansat-in-iulie-1971/.

Dima, A. M., \& Ghinea, V. (2016, November). A Model of Academic Leadership. In European Conference on Management, Leadership \& Governance (p. 61). Academic Conferences International Limited.

Dima, A. M., Hadad, S., \& Cantaragiu, R. (2016). A conceptual analysis of business-university knowledge transfers in the energy field. ENERGY, CLIMATE CHANGE AND SUSTAINABILITY, 201-207.

Fayolle, A. (2003). Le métier de créatuer d'entreprise, Paris: Editions d'organisation.

Fayolle, A. (2004). Entrepreneuriat: appendre à entreprendre, Paris: Dunod.

Fayolle, A., Filion, L.J. (2006). Devenir entrepreneur: des enjeux aux outils, Paris: Pearson Education France.

Lange, J., Marram, E., Brown, D., Marquis, J., and Bygrave, Willim. (2012). IS ENTREPRENEURSHIP A PROFESSION? (SUMMARY), Frontiers of Entrepreneurship Research: Vol. 32(5), Article 13.

Nicolescu, O. (2001). Managementul întreprinderilor mici şi mijlocii: concepte, metode, 
aplicatii, studii de caz, București: Editura Economică.

Nicolescu, O., Plumb, I., Pricop, M., Vasilescu, I., Verboncu, I. (coord.). (2003). Abordări moderne în management şi economia organizaţiei, Vol. 4, Bucureşti: Editura Economică.

Nicolescu, O., Verboncu, I. (1997). Management, ed. II, București: Editura Economică.

Teodorescu, V. (2013). Mandatarii în presa de altădată, Retrieved from PICBE | 474 http://www.evz.ro/cum-a-invins-stelatos-frizerul-indragostit-socialismul-luiceausescu-1033162.html. 